\title{
Differential Susceptibility of MDF and Commercial Wood to Coptotermes gestroi
}

\author{
Vinicius José Fernandes ${ }^{1}$ (D), Thiago Sampaio de Souza ${ }^{1}$ (D), Vinícius Gazal ${ }^{1}$ (D), \\ Elen de Lima Aguiar-Menezes ${ }^{1}$ (D), Eurípedes Barsanulfo Menezes ${ }^{1}$ \\ ${ }^{1}$ Universidade Federal Rural do Rio de Janeiro - UFRRJ, Seropédica/RJ, Brasil
}

\begin{abstract}
The present study evaluated the foraging and feeding preferences of Coptotermes gestroi (Blattodea: Rhinotermitidae) in wood from four forest species and Medium Density Fiberboard (MDF) in urban areas of the municipalities of Rio de Janeiro, São Gonçalo and Seropédica, RJ, Brazil. Wooden and MDF stakes were buried in the soil in the presence of C. gestroi foragers, in multiple choice assays, where the stakes remained for 15, 30, 60 and 90 days. The highest occurrence of foragers was in Alcântara 2 (São Gonçalo). In three areas, the stakes presented no foraging at any time during the exposure period. Generally, the longer the exposure period, the greater the occurrence of C. gestroi in the stakes and their loss of mass. The Pinus elliottii stakes had a greater loss of mass caused by C. gestroi, followed by the MDF, suggesting the need for preservative treatment of these materials prior to use.
\end{abstract}

Keywords: xylophagous termite, Medium Density Fiberboard, foraging behavior, cellulose material consumption. 


\section{INTRODUCTION}

According to information from Perlin (2005) and Carvalho (2008), since the beginning human civilizations, wood has been used to construct dwellings and manufacture utensils for diverse purposes, occupying a significant place in the development of human societies and presenting a range of uses both in rural and urban environments.

The Brazilian woods referred to as law or noble are appreciated for their quality and their resistance to biodegrading agents, and are used in civil and naval construction, furniture manufacturing, musical instruments and as sleepers for railway tracks (Gonzaga, 2006; Masieiro et al., 2017). However, to slow the exploitation of noble woods such as araucaria (Araucaria angustifolia), jacaranda (Dalbergia nigra), cedar (Cedrela fissilis) and mahogany (Swietenia macrophylla), forest plantations of Eucalyptus and Pinus were incentivized, reaching 7.2 million hectares in 2015, and representing 92.3\% of the total area of planted trees, to meet domestic and international demands for solid products, industrialized wood boards, paper and cellulose (IBÁ, 2016a).

Although, a much smaller area of forest plantations in Brazil is occupied by non-conventional species of commercial interest $(7.7 \%$ of the total forest plantations), which includes maçaranduba (Manilkara huberi), marupá (Schefflera morototoni) and tauari (Allantoma lineata) (IBÁ, 2016a). Maçaranduba wood is used by the timber industry to manufacture rafters, flooring, beams, roofing and furniture (IPT, 2017a), while tauari and marupá woods are widely used for civil construction, ceilings, skirting boards, door frames and picture frames (Carvalho, 2002; Melo et al., 2002).

However, wood panels emerged due to the need to reduce the consumption of solid wood from native forests and to raise awareness of the large scale timber industries regarding the greater use of forest residues. The production of Brazilian reconstituted wood boards was 7.5 million cubic meters in 2015 and, despite a drop in sales for this product on the domestic market, exports presented a growth of $52.3 \%$ (641 thousand cubic meters) in comparison with 2014 (IBÁ, 2016b).

Medium Density Fiberboard (MDF) is one of the main types of reconstituted timber board, standing out economically on the national and international markets, since they are more widely used by the furniture and civil construction industries, being able to substitute solid wood for diverse applications (Mattos et al., 2008; Freire et al., 2015; IBÁ, 2016b). The main raw materials for MDF boards produced in Brazil are eucalyptus and pinus timbers (Mattos et al., 2008).

Given the organic nature of its constituents, wood is subject to deterioration by biological agents, amongst which are xylophagous termites (Cavalcante, 1982). Of these termites, Coptotermes gestroi (Wasmann) (Blattodea: Rhinotermitidae) stands out. Originally a Southeast Asian species, it is considered an economically significant urban and agricultural pest that has established itself in many regions around the world, including South America (Kirton \& Brown, 2003; Jenkins et al., 2007; Li et al., 2013; Chouvenc et al., 2016).

In Brazil, C. gestroi, mainly found along the coastal region of southeastern Brazil, is considered one of the main pests in urban buildings, damaging structural timbers, furniture and different types of cellulose materials, such as books and picture frames (Constantino, 2002; Costa-Leonardo, 2002, 2007; Chouvenc et al., 2016).

Timber and other cellulose materials in buildings are accessed by C. gestroi foragers through the construction of ramified earth tunnels along electrical cables, pipe systems and inside cracks and breaks in walls or concrete foundations, generally starting from their nest constructed in the soil (Costa-Leonardo, 2002).

As Hapukotuwa \& Grace (2011) have highlighted, comparisons of the preferences for different woods are useful to select materials for construction under termite infestation conditions, and to identify material that requires preservative treatment prior to use. In Brazil, C. gestroi was already reported as consuming boards of diverse native and exotic forest species such as eucalyptus and pinus, in field conditions (Peralta et al., 2003, 2004; Trevisan et al., 2003; Souza et al., 2009), but information has not been encountered regarding attacks on MDF.

This study evaluated the foraging and feeding preferences of C. gestroi in wood with commercial interest (four forest species) and Medium Density Fiberboards (MDF) in urban areas of the municipalities of Rio de Janeiro, São Gonçalo and Seropédica, RJ, Brazil. 


\section{MATERIAL AND METHODS}

The experiments were conducted throughout the period from February to May, 2016 in eight urban areas distributed in Campo Grande, Padre Miguel and Santa Cruz (with two areas) in the city of Rio de Janeiro, two areas in Alcântara in the municipality of São Gonçalo and in the neighborhoods of UFRRJ and Canto do Rio in the municipality of Seropédica (Table 1).

All the areas are located outside residential zones and show the presence of C. gestroi foragers (workers and soldiers) active in the soil, where the test bodies were buried. In each area, termite specimens were collected and placed in $20 \mathrm{~mL}$ glass jars containing hydrated alcohol and taken to the laboratory of the Integrated Pest Management Center at the Entomology and Phytopathology Department of the Institute of Health and Biological Sciences of the Universidade Federal Rural do Rio de Janeiro (UFRRJ, Seropédica Campus, RJ) for conclusive identification based on Scheffrahn \& Su (2014).

The test bodies consisted of stakes with dimensions of $15.0 \mathrm{~cm} \times 2.3 \mathrm{~cm} \times 2.3 \mathrm{~cm}$ (longitudinal $\times$ radial $\times$ tangential) from four types of wood (pure core), with three being native forest species (Allantoma lineata, Lecythidaceae; Schefflera morototoni, Araliaceae; and Manilkara huberi, Sapotaceae), and one exotic (Pinus elliottii, Pinaceae) and material derived from the timber; MDF produced with pinus and eucalyptus fibers as raw materials. The cellulose materials used in the research were obtained in the form of beans from local businesses from the suburb of Santa Cruz, Rio de Janeiro, RJ. The timber species were macroscopically confirmed based on their characteristics described by Tomazello et al. (1983), IPT (2017a, b) and SNIF (2017). Pinus elliottii was used as a control given that wood from species of this genus are susceptible to termite attacks and therefore, considered a good indicator of termite activity levels (Bultman \& Southwell, 1976; Souza et al., 2009; Santos et al., 2010; IPT, 2017b).

The stakes, after weighing, (initial weight) in laboratory environmental conditions, were buried horizontally in the soil, in $20 \mathrm{~cm}$ deep holes, arranged randomly in groups of two stakes of each material (each one to the side of the other), in a multiple choice formation, at the C. gestroi foraging points, which varied according to the areas.

The materials were exposed to the action of the C. gestroi foragers for a period of 15, 30, 60 and 90 days after installation in each area, with 10 stakes for each period and 40 stakes for each area, for a total of 320 stakes. At the end of each exposure period, the stakes were removed and infestation by C. gestroi foragers (workers and soldiers) was evaluated in each stake, noting down the number of stakes showing presence of individuals, with or without loss of mass. The samples were placed in transparent plastic bags and taken to the laboratory to obtain the final mass of each one. The experimental design adopted was that of subdivided parcels, where the parcel represented the type of cellulose material and the sub-parcel, the exposure period of the stakes in the soil.

In the experimental installation at each site and during the evaluations, the temperature and relative air humidity were determined (Table 2), using a digital hygrometer (Instrutherm ${ }^{\circledR}$, model HT0700) previously calibrated to the level of the soil surface.

Table 1. The installation areas for the test bodies of the four forest timber species and for the MDF in three municipalities of the State of Rio de Janeiro and their geographic coordinates.

\begin{tabular}{|c|c|c|c|}
\hline Municipality and suburb & Latitude & Longitude & Altitude (m) \\
\hline \multicolumn{4}{|l|}{ Rio de Janeiro } \\
\hline Campo Grande & $22^{\circ} 52^{\prime} 45.03^{\prime \prime S}$ & $43^{\circ} 33^{\prime} 44.58^{\prime \prime} \mathrm{W}$ & 43.70 \\
\hline Padre Miguel & $22^{\circ} 52^{\prime} 52.62 ” \mathrm{~S}$ & $43^{\circ} 26^{\prime} 35.57^{\prime \prime} \mathrm{W}$ & 43.28 \\
\hline Santa Cruz 1 & $22^{\circ} 56^{\prime} 21.30^{\prime \prime} \mathrm{S}$ & $43^{\circ} 39^{\prime} 53.63^{\prime \prime} \mathrm{W}$ & 24.00 \\
\hline Santa Cruz 2 & $22^{\circ} 56^{\prime} 20.98^{\prime \prime S}$ & $43^{\circ} 39^{\prime \prime} 54.10^{\prime \prime} \mathrm{W}$ & 24.00 \\
\hline \multicolumn{4}{|l|}{ São Gonçalo } \\
\hline Alcântara 1 & $22^{\circ} 49^{\prime} 5.90^{\prime \prime} \mathrm{S}$ & $42^{\circ} 59^{\prime} 45.37^{\prime \prime} \mathrm{W}$ & 22.09 \\
\hline Alcântara 2 & $22^{\circ} 49^{\prime} 5.99^{\prime \prime} \mathrm{S}$ & $42^{\circ} 59^{\prime} 45.08^{\prime \prime} \mathrm{W}$ & 24.73 \\
\hline \multicolumn{4}{|l|}{ Seropédica } \\
\hline Canto do Rio & $22^{\circ} 51^{\prime} 48.79^{\prime \prime S}$ & $43^{\circ} 40^{\prime} 28.73^{\prime \prime} \mathrm{W}$ & 9.54 \\
\hline UFRRJ & $22^{\circ} 46^{\prime} 8.67^{\prime \prime} \mathrm{S}$ & $43^{\circ} 41^{\prime} 36.98^{\prime \prime} \mathrm{W}$ & 22.00 \\
\hline
\end{tabular}


Table 2. Climatic data from the installation area for the test bodies in the three municipalities from the state of Rio de Janeiro obtained at the start and on each evaluation date of the experiments.

\begin{tabular}{|c|c|c|c|c|c|c|c|c|c|c|c|c|}
\hline \multirow{3}{*}{ Area $^{a}$} & \multicolumn{12}{|c|}{ Days after installation of the experiment } \\
\hline & \multicolumn{2}{|c|}{$\mathbf{0}$} & \multicolumn{2}{|c|}{15} & \multicolumn{2}{|c|}{30} & \multicolumn{2}{|c|}{60} & \multicolumn{2}{|c|}{90} & \multicolumn{2}{|c|}{ Average } \\
\hline & $\mathbf{T}^{\mathbf{b}}$ & $\mathbf{U R}^{\mathrm{c}}$ & $\mathbf{T}$ & UR & $\mathbf{T}$ & UR & $\mathbf{T}$ & UR & $\mathbf{T}$ & UR & $\bar{T}$ & UR \\
\hline AL1 & 34.2 & 58 & 33.4 & 61 & 31.9 & 62 & 37.0 & 46 & 28.9 & 76 & 33.1 & 60.6 \\
\hline AL2 & 33.2 & 55 & 38.4 & 44 & 34.5 & 41 & 29.4 & 67 & 23.6 & 58 & 31.8 & 53.0 \\
\hline CGR & 34.9 & 57 & 31.8 & 66 & 32.2 & 74 & 28.8 & 67 & 26.9 & 78 & 30.9 & 68.4 \\
\hline CRI & 28.8 & 84 & 28.0 & 69 & 29.4 & 80 & 30.3 & 72 & 23.1 & 62 & 27.9 & 73.4 \\
\hline PMI & 37.6 & 50 & 29.6 & 80 & 30.2 & 72 & 27.8 & 71 & 28.9 & 72 & 30.8 & 69.0 \\
\hline SCR1 & 27.9 & 91 & 27.9 & 77 & 31.9 & 77 & 26.6 & 87 & 24.3 & 75 & 27.7 & 81.4 \\
\hline SCR2 & 28.0 & 88 & 27.6 & 78 & 31.9 & 81 & 28.1 & 89 & 23.8 & 80 & 27.7 & 83.2 \\
\hline UFR & 39.8 & 22 & 32.3 & 68 & 45.8 & 23 & 23.4 & 62 & 24.2 & 67 & 33.1 & 48.4 \\
\hline
\end{tabular}

${ }^{\mathrm{a}} \mathrm{AL} 1$ = Alcântara 1; AL2 = Alcântara 2; CGR = Campo Grande; CRI = Canto do Rio; PMI = Padre Miguel; SCR1 = Santa Cruz 1; SCR2 = Santa Cruz 2; UFR = UFRRJ; ${ }^{\mathrm{b}} \mathrm{T}=$ Air temperature $\left({ }^{\circ} \mathrm{C}\right) ;{ }^{\mathrm{c}} \mathrm{UR}=$ Relative air humidity $(\%)$.

The foraging in the samples was evaluated by the frequency of occurrence of C. gestroi foragers (workers and soldiers), which was determined by the number of stakes infested by these individuals divided by the total number of buried stakes $\mathrm{x} 100 \%$. The comparison of the data was realized using the chi-square test with the help of the STATISTICS 10.0 program. The level of probability by which a comparison was considered significant was $\mathrm{p}<0.05$.

Loss of mass of cellulose material was determined by the difference between the dry weight of the stakes when they were buried (initial mass) and their dry weight during each exposure period (final mass). The analysis of normality of errors was realized using the Kolmogorov-Smirnov/Lilliefor (0.1\%) test. In taking this presupposition into account, the loss of mass data was analyzed using ANOVA and the averages compared using the Tukey test $(\mathrm{p}<0.05)$. These analyses were realized with the help of the STATISTICS 10.0 program.

\section{RESULTS AND DISCUSSION}

Coptotermes gestroi workers and soldiers foraged $12.5 \%(\mathrm{~N}=40)$ of the total stakes buried in the eight evaluated areas $(\mathrm{N}=320)$. In these areas, the presence of other termite species was not observed, nor was the action of other xylophagous organisms macroscopically evident, as Peralta et al. $(2003,2004)$ and Trevisan et al. (2003) had reported. Therefore, C. gestroi was considered the main agent that acted in the samples. C. gestroi occurrence was greater in the stakes buried in Alcântara 2 (15\% of the stakes showing presence of foragers) when compared with those buried in Santa Cruz 1 (5\%), which did not differ significantly from the occurrence of C. gestroi in Campo Grande (10\%), Canto do Rio (10\%) and Padre Miguel (8\%) (test $\left.\chi^{2}=4.5 ; \mathrm{df}=4 ; \mathrm{p}<0.05\right)$.

Occurrence of C. gestroi foragers was not found in samples buried in Alcântara 1, Santa Cruz 2 and UFRRJ during the four exposure periods, nor by other termite species or by other xylophagous organisms, though at the time of installation of the stakes foraging by C. gestroi was evident.

The absence of foraging in the stakes installed in Alcântara 1 and UFRRJ was possibly caused by the appearance of predatory ants or opportunists that were observed when the samples were unearthed after 15 days of exposure in the soil. Jaffe et al. (1995) reported that some ant species are aggressive predators of termites and also exploit the site that termites occupy as a potential nesting place.

In Santa Cruz 2, the presence of a large nuber of excess planks and eucalypt and pine fence posts (timber used in construction works), previously attacked by C. gestroi, may have attracted them to these food sources, resulting in the absence of foragers from the stakes buried in this area.

The absence of foraging by C. gestroi in stakes from native forest species and Pinus sp. was observed by Souza et al. (2009) in a residential area in the suburb Ecologia (Seropédica, RJ) over the time when they were buried in the soil $(90,180$ and 270 days after being buried) though the occurrence of this termite 
had been previously reported in this area. According to these authors, the absence of foraging and, therefore, of loss of mass of these stakes may have been caused by the availability of other food sources in the area, such as dry leaves, branches fallen on the ground and even tree trunks, which are normally reported as attacked by C. gestroi in urban areas (Costa-Leonardo, 2002, 2007).

Santos et al. (2010) verified that in environments with a greater availability of ground cover and lower luminosity, such as the interior of forests, C. gestroi attacks on Pinus stakes used as trap baits, were significantly lower than in the Cerrado and grassy areas where the scarcity of other sources allowed the localization and attacking of the baits by C. gestroi foragers.

Visual analysis of the stakes when they were buried (Figure 1a), compared with after a period of exposure in the soil (Figure 1b), allowed us to observe that C. gestroi foraged in all four types of wood and the MDF, consuming almost all the P. elliottii and MDF stakes, a little from the woods $A$. lineata and S. morototoni but were unable to consume $M$. huberi.

The attack capacity of $C$. gestroi on these materials can be related to their ability to better use the area in which they foraged in search of food, moving about in a diffuse manner simultaneously exploring the different food types, thereby trying to consume the available food sources in a more effective way (Arab et al., 2005).

Rodrigues \& Brito (2011), showed, under laboratory conditions, that the test bodies of $P$. elliottii wood were also intensively attacked by C. gestroi, presenting perforations, in comparison with those of Corymbia citriodora and Eucalyptus urophylla, which presented superficial attacks, without rupture or penetration of the wood.

In terms of long term foraging, the occurrence of C. gestroi at 60 and 90 days of exposure of the material in the soil $[15 \%$ and $8 \%$ of the total stakes $(\mathrm{N}=80)$, respectively] did not differ significantly from one another, but was greater than at 15 days (1\%), which did not differ significantly from the occurrence after 30 days $(0 \%)$ (Test $\left.\chi^{2}=11.5 ; \mathrm{df}=3 ; \mathrm{p}<0.001\right)$.

This result could in part be explained by the perturbations caused by the soil to the foraging C. gestroi population which may have coincided with the initial phase of the establishment of termite foraging in the stakes during the first 30 days after the installation of the experiment. The start of this phase occurred beginning from the construction of the foraging trails by the workers together with the soldiers, probably to search for food resources, followed by the recruitment of other individuals from the colony to start the exploration of these resources after encountering potential food sources, presenting behavior similar to that described by Bordereau \& Pasteels (2010) for other termite species.

In all the exposure periods, independent of the material, there was a loss of mass of the stakes caused by C. gestroi. However, the loss of mass of the samples at 60 days $(2.3 \pm 0.91 \mathrm{~g})$ did not differ significantly from those exposed after 90 days $(3.01 \pm 1.08 \mathrm{~g})$, and both presented greater loss of mass than those at 15 days $(0.05 \pm 0.04 \mathrm{~g})$ or 30 days $(0.04 \pm 0.02 \mathrm{~g})\left(\mathrm{F}_{3,280}=4.78\right.$;
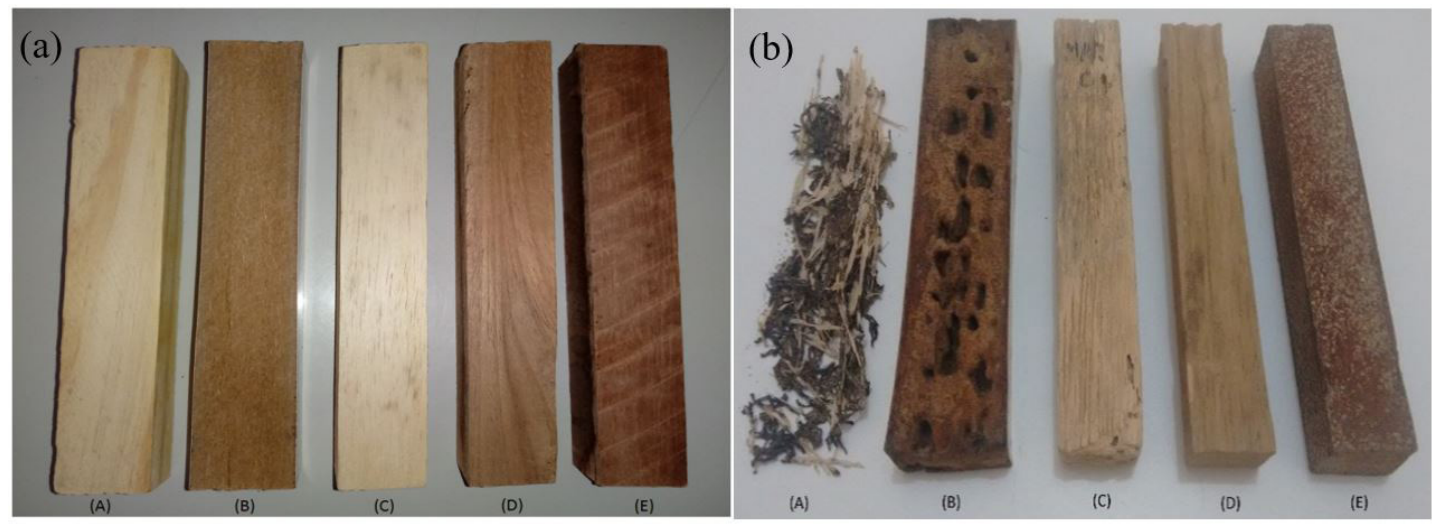

Figure 1. (a) Wooden stakes of the four forest species and of MDF prior to exposure in the soil and (b) after being attacked by Coptotermes gestroi. (A) Pinus elliottii; (B) MDF; (C) Schefflera morototoni; (D) Allantoma lineata; and (E) Manilkara huberi. 
$\mathrm{p}<0.01$ ), though there was no occurrence of C. gestroi foragers in the second evaluation of the stakes, indicating a prior attack on the wood and MDF. These results corroborate those of Souza et al. (2009), who found that the loss of mass of the wood of five forest species due to $C$. gestroi increased over time, suggesting that wood resistance diminished over time due to exposure to the termites.

It is possible that the loss of mass of the materials buried in the soil due to $C$. gestroi over time was favored by the breakdown of extractive toxins, that are repellent or deterrent to termites and that are present in the forest species, mainly in the native species. These give natural durability to the wood against the action of the degrading insects, as demonstrated by Bultman \& Southwell (1976), Bultman et al. (1979) and Nascimento et al. (2013). Chang et al. (2001) showed, under laboratory conditions, that the natural resistance of Taiwania cruptomerioides wood to Coptotermes formosanus can be attributed to the anti-termite activity of cedrol and $\alpha$-cardinol.

In relation to the five materials evaluated, the percentages of occurrence of $C$. gestro $i$ in the stakes did not differ statistically from each other, being $9 \%$ in the MDF and P. elliottii, 6\% in S. morototoni, 3\% in A. lineata and $2 \%$ in $M$. huberi (test $\chi^{2}=0.3$; $\mathrm{df}=4$; n.s.) (Figure 2). These results indicate that this termite investigated these materials as possible cellulose and hemicellulose sources, given that they constitute a basic food source for xylophagous termites (Medeiros, 2004).
C. gestroi workers consumed greater wood mass of $P$. elliottii $(3.69 \pm 1.36 \mathrm{~g})$ than of $A$. lineata or $S$. morototoni, however this did not differ from the MDF stakes $(2.69 \pm 1.11 \mathrm{~g})\left(\mathrm{F}_{3,280}=4.71 ; \mathrm{p}<0.01\right)$ (Figure 3). Arab et al. (2005) estimated that the rate of consumption of the Pinus sp. stakes by C. gestroi was $26.76 \pm 6.86 \mathrm{~g}$ by 90 days.

The coincidence between the greater occurrence of C. gestroi and the greater loss of mass of the P. elliottii stakes could be related to wood density $\left(0.40 \mathrm{~g} \mathrm{~cm}^{-3}\right)$, which is the lowest amongst the forest species evaluated $\left(0.57 \mathrm{~g} \mathrm{~cm}^{-3}\right.$ para S. morototoni, $0.60 \mathrm{~g} \mathrm{~cm}^{-3}$ for A. lineata and $1.04 \mathrm{~g} \mathrm{~cm}^{-3}$ for M. huberi) (Tomazello et al., 1983; IPT, 2017a, b; Santos \& Del Menezzi, 2010), while MDF presented a density of around $0.50 \mathrm{~g} \mathrm{~cm}^{-3}$ (Maloney, 1993).

According to Bultman et al. (1979), the existence of a relation between wood density and resistance to termites is comprehensible, given that the hardness of the wood affects the ability of termites to break it apart with their mandibles prior to ingestion (Waller \& La Fage, 1987). Therefore, less dense woods tend to suffer damage more easily from these insects than the many hard and heavier woods, with higher density (above $0.80 \mathrm{~g} \mathrm{~cm}^{-3}$ ). In fact, in the present study, the $M$. huberi stakes were foraged, even noting trail marks characterized by the adherence of soil and feces (Figure 1b), but they were not consumed by C. gestroi. $M$. huberi wood is considered hard to cut and of high density, varying from 0.83 to $0.87 \mathrm{~cm}^{-3}$ (Silveira et al., 2013; IPT, 2017a).

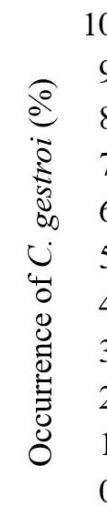

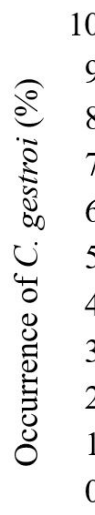

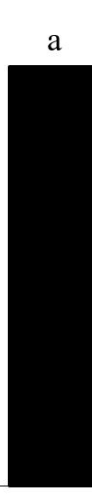

a

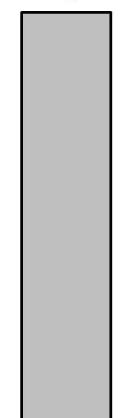

- Pinus elliottii $\square \mathrm{MDF}$

$\square$ Schefflera morototoni

- Allantoma lineata

$\boldsymbol{\nabla}$ Manilkara huberi

\section{a}

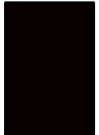

a

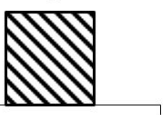

Cellulose material

Figure 2. Percentage of Coptotermes gestroi occurrence in the wooden stakes of four forest species and MDF (N =64). Averages followed by the same letter did not differ from one another by the chi-square test $(\mathrm{p}>0.05)$. 


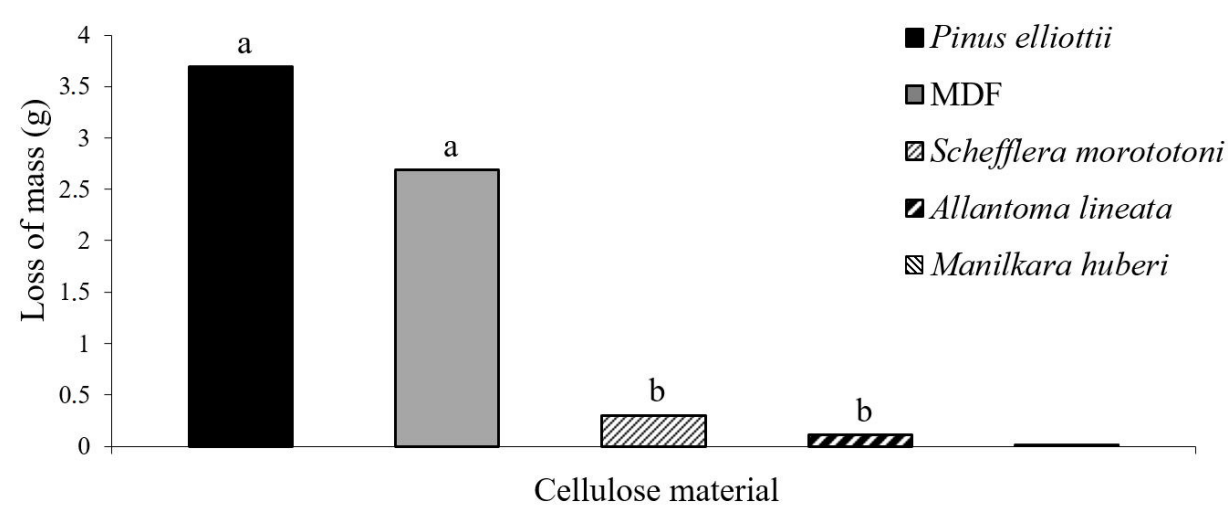

Figure 3. Loss of mass of wooden stakes of the four forest species and MDF caused by Coptotermes gestroi $(\mathrm{N}=64)$. Averages followed by the same letter did not differ from each other by Tukey test $(\mathrm{p}>0.05)$.

Souza et al. (2009) obtained a negative correlation between wood density in five forest species and the loss of mass of the stakes due to C. gestroi. In the 10 installation sites of the stakes presenting C. gestroi activity in the Seropédica campus of the UFRRJ, these authors observed that $M$. huberi stakes were consumed in only two places, however at 270 days after installation, when the mass consumed was at the most $1.35 \mathrm{~g}$, the weight loss of the Pinus sp. stakes $\left(0.42 \mathrm{~g} \mathrm{~cm}^{-3}\right.$ density) was $15.25 \mathrm{~g}$.

Behavior similar to the C. gestroi observed in this study seems to be exhibited by C. formosanus in a laboratory assay performed by Bultman et al. (1979), given that Pinus elliottii var. elliottii, with an average density of $0.54-0.59 \mathrm{~g} \mathrm{~cm}^{-3}$ was significantly damaged by these insects and $90 \%$ of the individuals $(n=50)$ survived throughout the whole period of the assay (56 days), while Manilkara multinervis $\left(1.09 \mathrm{~g} \mathrm{~cm}^{-3}\right)$ was not damaged and $100 \%$ if the individuals died within 21 days.

Hapukotuwa \& Grace (2011) studied the preferences of C. formosanus and C. gestroi for three commercial conifer species in the United States, in multiple choice assays in the laboratory. The authors found that both termite species damaged the conifer wood, however, there was a greater weight loss of Pinus sp. wood $(27.98 \pm 10.63 \%)$ caused by C. formosanus attacks in comparison with C. gestroi (13.85 $\pm 9.35 \%)$, with this difference possibly being a reflection of the size of the foraging caste or of the activity levels between these two species.
Rodrigues \& Brito (2011) found, under laboratory conditions, that C. gestroi caused weight loss of the P. elliottii test bodies of $3.85 \%$, which was significantly greater than C. citriodora (2.89\%) and E. urophylla (2.86\%), and considered the density of the wood and the chemical composition of the P. elliottii logs as possible determining factors for greater susceptibility.

However, less dense woods can also be less damaged by termites, generally due to their containing extractive anti-termite toxins. Trevisan et al. (2007) observed that despite the Melia azedarach wood possessing a lower density $\left(0.44\right.$ to $\left.0.49 \mathrm{~g} \mathrm{~cm}^{-3}\right)$, it was less attacked by xylophagous organisms. Manzoor et al. (2015) considered the wood of this Meliaceae as resistant to attack by Coptotermes heimi, showing a minimum weight loss $(0.10 \pm 0.006 \mathrm{~g})$ at 14 days under laboratory conditions.

In a general analysis, the results obtained indicated that the use of Pinus elliottii wood and MDF sold in the local businesses required care by furniture manufactures and in civil construction to guard against C. gestroi action, such as the use of preservative treatments to increase the durability of these materials. For example, Kartal \& Green (2003) concluded that the MDFs may require the incorporation of chemical biocides prior to the manufacture of the boards to increase their resistance to termite attacks. Rowell (2014) showed that acetylation of Pinus merkusii caused $100 \%$ mortality of the C. gestroi individuals and $1.7 \%$ weight loss in comparison with the control, with $70 \%$ mortality and $9.9 \%$ loss. 


\section{CONCLUSIONS}

The presence of Coptotermes gestroi foragers in activity in a determined area does not guarantee that they will act to infest wood or Medium Density Fiberboard (MDF) when available in the soil for, at least, a period of 90 days.

The wood of Allantoma lineata, Manilkara huberi, Pinus elliottii, Schefflera morototoni and the MDF are equally foraged by C. gestroi, with the occurrence of foraging being greater with the increase of the exposure period of these materials in the soil.

In multiple choice situations, under field conditions, C. gestroi showed the following feeding preferences, in decreasing order, based on the loss of mass of the cellulosic materials evaluated; $P$. elliottii $>M D F>$ A. lineata $\cong S$. morototoni $>$ M. huberi.

\section{ACKNOWLEDGEMENTS}

We thank CAPES (Coordenação de Aperfeiçoamento de Pessoal de Nível Superior) for the magister science scholarship to the first author. Thanks also to the householders for allowing the installation of experiments on their residencies.

\section{SUBMISSION STATUS}

Received: 2 may, 2017

Accepted: 24 jan., 2018

\section{CORRESPONDENCE TO}

\section{Vinicius José Fernandes}

Programa de Pós-graduação em Fitossanidade e Biotecnologia Aplicada, Universidade Federal Rural do Rio de Janeiro - UFRRJ, Rodovia BR 465, Km 7, CEP 23897-000, Seropédica, RJ, Brasil e-mail: vinicjfagro@gmail.com

\section{REFERENCES}

Arab A, Costa-Leonardo AM, Casarin FE, Guaraldo ADC, Chaves RC. Foraging activity and demographic patterns of two termite species (Isoptera: Rhinotermitidae) living in urban landscapes in southeastern Brazil. European Journal of Entomology 2005; 102(4): 691-697. http:// dx.doi.org/10.14411/eje.2005.098.
Bordereau C, Pasteels JM. Pheromones and chemical ecology of dispersal and foraging in termites. In: Bignell DE, Roisin Y, Lo N, editors. Biology of termites: a modern synthesis. Dordrecht: Springer; 2010. http://dx.doi. org/10.1007/978-90-481-3977-4_11.

Bultman JD, Beal RH, Ampong FFK. Natural resistance of some tropical African woods to Coptotermes formasanus Shiraki. Forest Products Journal 1979; 29(6): 46-51.

Bultman JD, Southwell CR. Natural resistance of tropical American woods to terrestrial wood-destroying organisms. Biotropica 1976; 8(2): 71-95. http://dx.doi. org/10.2307/2989627.

Carvalho PER. Mandiocão. Colombo: Embrapa Floresta; 2002.

Carvalho RP. O uso da madeira aplicado ao ensino da arte em sala de aula a partir do processo civilizatório, da utilização da madeira pelo homem e seus valores artísticos: módulo I. Revista Filosofia Capital 2008; 3(6): 73-95.

Cavalcante MS. Deterioração biológica e preservação de madeiras. São Paulo: IPT; 1982.

Chang S-T, Cheng S-S, Wang S-Y. Antitermitic activity of essential oils and components from taiwania (Taiwania cryptomerioides). Journal of Chemical Ecology 2001; 27(4): 717-724. http://dx.doi.org/10.1023/A:1010397801826. PMid:11446295.

Chouvenc T, Li H-F, Austin J, Bordereau C, Bourguignon T, Cameron SL et al. Revisiting Coptotermes (Isoptera: Rhinotermitidae): a global taxonomic road map for species validity and distribution of an economically important subterranean termite genus. Systematic Entomology 2016; 41(2): 299-306. http://dx.doi.org/10.1111/syen.12157.

Constantino R. The pest termites of South America: taxonomy, distribution and status. Journal of Applied Entomology 2002; 126(7-8): 355-365. http://dx.doi. org/10.1046/j.1439-0418.2002.00670.x.

Costa-Leonardo AM. Coptotermes havilandi. In: CostaLeonardo AM, editor. Cupins-praga: morfologia, biologia e controle. Rio Claro: Divisa; 2002.

Costa-Leonardo AM. O cupim Coptotermes gestroi: uma realidade que veio para ficar. Vetores \& Pragas 2007; 17: 2-5.

Freire ALF, Figueirêdo MCB, Rosa MF, Araújo CP Jr. Impactos ambientais de painéis de madeira e derivados: uma revisão de literatura. Espacios [online] 2015; 36(10): 1-3 [cited 2017 July 23]. Available from: http://www. revistaespacios.com/a15v36n10/15361004.html

Gonzaga AL. Madeira: uso e conservação. Brasília: IPHAN/ MONUMENTA; 2006.

Hapukotuwa NK, Grace JK. Preferences of Coptotermes formosanus Shiraki and Coptotermes gestroi (Wasmann) (Blattodea: Rhinotermitidae) among three commercial wood species. Insects 2011; 2(4): 499-508. http://dx.doi. org/10.3390/insects2040499. PMid:26467829. 
Indústria Brasileira de Árvores - IBÁ. Desempenho das árvores plantadas: relatório anual 2016. Brasília: IBÁ; 2016 a.

Indústria Brasileira de Árvores - IBÁ. Desempenho industrial: relatório anual 2016. Brasília: IBÁ; 2016 b.

Instituto de Pesquisas Tecnológicas do Estado de São Paulo - IPT. Informações sobre madeiras, maçaranduba. São Paulo: IPT; 2017a [cited 2017 July 23]. Available from: http://www.ipt.br/informacoes_madeiras/4.htm

Instituto de Pesquisas Tecnológicas do Estado de São Paulo - IPT. Informações sobre madeiras, pinus-eliote. São Paulo: IPT; 2017b [cited 2017 July 23]. Available from: http://www.ipt.br/informacoes_madeiras3.php?madeira=7

Jaffe K, Ramos C, Issa S. Trophic interactions between ants and termites that share common nests. Annals of the Entomological Society of America 1995; 88(3): 328-333. http://dx.doi.org/10.1093/aesa/88.3.328.

Jenkins TM, Jones SC, Lee C-Y, Forschler BT, Chen Z, Lopez-Martinez G et al. Phylogeography illuminates maternal origins of exotic Coptotermes gestroi (Isoptera: Rhinotermitidae). Molecular Phylogenetics and Evolution 2007; 42(3): 612-621. http://dx.doi.org/10.1016/j. ympev.2006.11.024. PMid:17254806.

Kartal SN, Green F 3rd. Decay and termite resistance of medium density fiberboard (MDF) made from different wood species. International Biodeterioration \& Biodegradation 2003; 51(1): 29-35. http://dx.doi. org/10.1016/S0964-8305(02)00072-0.

Kirton LG, Brown VK. The taxonomic status of pest species of Coptotermes in Southeast Asia: resolving the paradox in the pest status of the termites, Coptotermes gestroi, C. havilandi and C. travians (Isoptera: Rhinotermitidae). Sociobiology 2003; 42(1): 43-63.

Li HF, Fujisaki I, Su N-Y. Predicting habitat suitability of Coptotermes gestroi (Isoptera: Rhinotermitidae) with species distribution models. Journal of Economic Entomology 2013; 106(1):311-321. http://dx.doi.org/10.1603/EC12309. PMid:23448046.

Maloney TM. Modern particleboard and dry-process fiberboard manufacturing. San Francisco: M. Freeman; 1993.

Manzoor F, Abbas M, Latif UM. Comparative study of resistance and feeding preference of 24 wood species to attack by Heterotermes indicola (Wasmann) and Coptotermes heimi (Isoptera: Rhinotermitidae) in Pakistan. Sociobiology 2015; 62(3): 417-425. http://dx.doi. org/10.13102/sociobiology.v62i3.732.

Masieiro CC, Gianezini M, Watanabe M, Yamaguchi CK. Estratégias para comercialização interestadual de madeiras de lei: um estudo de caso nos estados de Rondônia e Santa Catarina [online]. Convibra; 2017 [cited 2017 July 23]. Available from: http://www.convibra.com.br/upload/ paper/2014/32/2014_32_10360.pdf

Mattos RLG, Gonçalves RM, Chagas FB. Painéis de madeira no Brasil: panorama e perspectivas. BNDES
Sectorial [online] 2008; 27: 121-156 [cited 2017 July 23]. Available from: https://web.bndes.gov.br/bib/jspui/ handle/1408/2526

Medeiros MB. Metabolismo da celulose em Isoptera. Biotecnologia Ciencia \& Desenvolvimento 2004; 7(33): 76-81.

Melo JE, Valle IMR, Mello RL, Souza MR. Habitação popular em madeira. Brasília: LPF; 2002.

Nascimento MS, Santana ALBD, Maranhão CA, Oliveira LS, Bieber L. Phenolic extractives and natural resistance of wood. In: Chamy R, Rosenkranz F, editors. Biodegradation: life of science. Rijeka: InTech; 2013. http:// dx.doi.org/10.5772/56358.

Peralta RCG, Menezes EB, Carvalho AG, Aguiar-Menezes EL. Feeding preference of subterranean termites for forest species associated or not to wood-decaying fungi. Floresta e Ambiente 2003; 10(2): 58-63.

Peralta RCG, Menezes EB, Carvalho AG, Aguiar-Menezes EL. Wood consumption rates of forest species by subterranean termites (Isoptera) under field conditions. Revista Árvore 2004; 28(2): 283-289. http://dx.doi.org/10.1590/S010067622004000200015 .

Perlin J. A forest journey: the role of wood in the development of civilization. Vermont: The Countryman Press; 2005.

Rodrigues RB, Brito EO. Resistência natural de Eucalyptus urophylla e Corymbia citriodora à Coptotermes gestroi (Isoptera; Rhinotermitidae) em laboratório. Floresta e Ambiente 2011; 18(1): 9-15. http://dx.doi.org/10.4322/ floram.2011.018.

Rowell RM. Acetylation of wood - a review. International Journal of Lignocellulosic Products [online] 2014; 1(1): 1-27 [cited 2017 July 23]. Available from: http://ijlp.gau.ac.ir/ article_1920_030939ec16feb1297e84cbd62e5f3f37.pdf

Santos CMT, Del Menezzi CHS. Efeito da gramatura sobre a resistência ao cisalhamento da linha de cola de duas madeiras tropicais: seru (Allantoma lineata) e marupá (Simarouba amara). Floresta 2010; 40(2): 345-354. http:// dx.doi.org/10.5380/rf.v40i2.17830.

Santos MN, Teixeira MLF, Pereira MB, Menezes EB. Avaliação de estacas de Pinus sp. como isca-armadilha em diversos períodos de exposição a cupins subterrâneos. Floresta 2010; 40(1): 29-36. http://dx.doi.org/10.5380/ rf.v40i1.17096.

Scheffrahn RH, Su N-Y. Asian subterranean termite Coptotermes gestroi (= havilandi) (Wasmann) (Insecta: Isoptera: Rhinotermitidae). Gainesville: IFAS Extension, University of Florida; 2014.

Silveira LHC, Rezende AV, Vale AT. Teor de umidade e densidade básica da madeira de nove espécies comerciais amazônicas. Acta Amazonica 2013; 43(2): 179-184. http:// dx.doi.org/10.1590/S0044-59672013000200007.

Sistema Nacional de Informações Florestais - SNIF. Banco de dados de espécies de madeiras brasileiras [online]. Brasília: SNIF; 2017 [cited 2017 Dec 2]. Available from: 
http://sistemas.florestal.gov.br/madeirasdobrasil/pesquisa. php?idioma= portugues

Souza JH, Menezes ELA, Mauri R, Menezes EB. Susceptibility of five forest species to Coptotermes gestroi. Revista Árvore 2009; 33(6): 1043-1050. http://dx.doi.org/10.1590/S010067622009000600007 .

Tomazello M Fo, Chimelo JP, Garcia PV. Madeiras de espécies florestais do estado do Maranhão: II. caracterização anatômica. IPEF 1983; 23: 29-36.

Trevisan H, Nadai JD, Lunz AM, Carvalho AG. Ocorrência de térmitas subterrâneos (Isoptera: Rhinotermitdae e Termitidae) e durabilidade natural da madeira de cinco essências florestais. Ciência Florestal 2003; 13(2): 153-158. http://dx.doi.org/10.5902/198050981751.

Trevisan H, Tieppo FMM, Carvalho AG, Lelis RCC. Avaliação de propriedades físicas e mecânicas da madeira de cinco espécies florestais em função da deterioração em dois ambientes. Revista Árvore 2007; 31(1): 93-101. http://dx.doi.org/10.1590/S0100-67622007000100011.

Waller DA, La Fage JP. Nutritional ecology of termites. In: Slansky F Jr, Rodriguez JG, editors. Nutritional ecology of insects, mites, spiders and related invertebrates. New York: John Willey \& Sons; 1987. 